\title{
Recent developments at International Psychogeriatrics
}

\section{Introduction}

The past eighteen months have seen a number of new developments for this journal. These include the conclusion of a new contract between the journal's owner, the International Psychogeriatric Association (IPA), and our publisher, Cambridge University Press (CUP); the appointment of a new editor-elect to take over from me as editor-in-chief next year; the addition of three new deputy editors to bring the total of such appointees, who assist the editor in chief, to four; and the development and implementation of an online submission and review system to speed the processing of submissions.

\section{New contract}

After extensive negotiations IPA and CUP finalized a new ten-year publishing contract in 2009 , which will ensure that for the first time IPA will receive a guaranteed minimum income from its ownership of International Psychogeriatrics, with the possibility of additional income if the journal performs as well as we hope and expect that it will. The agreement commits CUP to increase the number of annual issues from six in 2009 to eight this year and, via the intermediate step of ten issues per annum, to twelve yearly issues no later than 2013, and to develop and implement an online submission and review system (see below). IPA and CUP will work together on other publishing ventures, starting with, but not limited to, the new Guide to Psychiatry of Old Age (Ames et al., 2010) on which IPA members will receive a $25 \%$ discount. Finally, CUP has agreed to become a corporate partner of IPA. These developments bring long-term security to the journal and are an expression of confidence by both partners in the future of both the journal and subspecialty which is its focus.

\section{New editor-elect}

Many readers will have seen the advertisements run in late 2008 and early 2009 inviting applications for a new editor-in-chief of International Psychogeriatrics, to take over from early 2011. Consistent with the IPA bylaws, no editor-in-chief

First published online 19 May 2010. can serve more than two four-year terms. My first term commenced on the date of my predecessor's resignation on 3 January 2003 (Robin Eastwood's $65^{\text {th }}$ birthday), so I must relinquish the editorship no later than 3 January 2011. Following the call for applicants, five applications for the position were received. The appointments committee consisted of Masatoshi Takeda, then IPA President-elect (IPA president since September 2009), Leonardo Pantoni, chairman of IPA's publications committee, Susan Oster, IPA executive director and the journal's managing editor, and myself as current editor-in-chief. After reviewing all the applications the appointments committee conducted telephone interviews with two applicants and then prepared a recommendation for the IPA Board of Directors to consider at its September 2009 meeting in Montreal, immediately preceding the IPA XIV Congress. At that meeting, after reviewing the recommendation of the appointments committee, the Board voted unanimously to appoint Professor Nicola Lautenschlager as editor-elect with the intention that she would become editor-in-chief for an initial four-year term from 3 January 2011.

Professor Lautenschlager trained in medicine and then psychiatry in Munich, Germany, where her supervisors included Professor Alexander Kurz. Her research training in old age psychiatry included a year in Boston. In 2000 she took up a position as senior lecturer at the University of Western Australia in Perth, where she was rapidly promoted, first to Associate Professor and later to Professor of Psychiatry of Old Age, reflecting her success in grant applications, research performance and publications, and her strong commitment to both undergraduate and postgraduate teaching and to clinical work. Of many influential publications deriving from her time in Western Australia, the best known addresses the effect of exercise in a population of older people with mild memory impairment (Lautenschlager et al., 2008). In July 2008 Professor Lautenschlager took up an appointment as University of Melbourne Professor of Psychiatry of Old Age at the St George's Hospital campus of St Vincent's Health in the Melbourne suburb of Kew, which I had vacated on my appointment as Director of the National Ageing Research Institute. Not only is she an outstanding choice to replace me as editor-in-chief of International Psychogeriatrics, but our co-location 
in the same city, and the close working relationship that we enjoy, will enable a smooth, gradual handover of editorial responsibilities which will be complete by the start of 2011, when she will set out her vision and aspirations for the future of this journal in an initial editorial. I am sure that all IPA members, and all International Psychogeriatrics readers, authors and reviewers, will provide her with the same level of enthusiastic support and assistance that I have been privileged to receive over the two terms of my editorship.

\section{Deputy and associate editors}

In the last eight years the rate of submissions to International Psychogeriatrics has more than quintupled, and the journal has increased in size from 392 published quarto pages in 2003 to 1408 A4 pages this year (Ames, 2009). It is no longer possible for an editor-in-chief and a part-time editorial assistant to run the journal without a great deal of support and assistance from a team of colleagues. For this reason, with the full support of the managing editor and the chairman of the IPA publications committee, my successor and I have expanded the number of deputy editors to four with immediate effect. John O'Brien had agreed to continue to bring his immense experience and ability to the journal's aid as deputy editor, while Nancy Pachana, an American-trained clinical psychologist and academic from Brisbane Australia, Guk-Hee Suh, an academic old age psychiatrist and member of the IPA Board of Directors from Seoul, Korea and Craig Ritchie, one of the most talented of the younger generation of old age psychiatrists from the U.K. have agreed to join him in deputy editor positions. Dr Ritchie will take responsibility for coordinating the journal's supplements and special issues, while the other three deputy editors will assume part of the task of assessing and deciding upon the acceptance, revision or rejection of papers submitted to the journal, leaving the editor-in-chief with more time to determine and direct the journal's overall strategy and direction. Most other successful journals delegate editorial responsibility to deputy or section editors and in taking this step we are acknowledging that the journal has moved on to a new phase in its development.

The terms of all associate editors of International Psychogeriatrics automatically expire upon the retirement of the editor in chief and the incoming editor will then have the discretion to appoint her own panel of associate editors from the extensive ranks of IPA members (some years ago the editorial panel determined that IPA membership would be the sole prerequisite for appointment as an associate editor).

\section{Online submission system}

As noted above, by mid-2009 the rapid growth in the number of submissions had reached a level where it was starting to overwhelm the existing submissions system, the part-time editorial assistant, and myself. We had planned for some time to introduce an online submission system, but this implementation was delayed until negotiations over the new contract between IPA and CUP were concluded, the quality and standard of submission systems had reached acceptable levels of reliability and user friendliness, and, most importantly, until I could devote sufficient time to train in the use of the new system. Taylor Bowen set up our current system while I was on study leave in London in the last quarter of 2009 and the whole thing went live in January 2010. In addition to expressing my appreciation of Taylor Bowen's efforts in designing such a straightforward, reliable and sensible system, I would like to thank Julia Hochbach of CUP for her prompt, effective and helpful ongoing technical support and to acknowledge the central role of our editorial assistant Marilyn Kemp in making this new system run as efficiently as everything else that she has undertaken for the journal in nearly eight years as editorial assistant. Marilyn's well-earned retirement from this post at the end of 2010 will be the largest challenge faced by my successor.

\section{Where to from here?}

We plan to run three special issues focusing upon training in psychogeriatrics, psychiatry in long-term care homes, and prevention in psychogeriatrics over the next few months. I will write a final editorial reflecting on my eight years as editor, which will appear early in 2011 and my successor will set out her vision in an initial editorial in the issue that follows my farewell editorial. But whatever happens at International Psychogeriatrics, the scope and significance of our field of endeavor seems set to continue its expansion into the second decade of the 21 st century.

\section{DAVID AMES}

Editor-in-chief International Psychogeriatrics

Melbourne, Australia

email: ipaj-ed@unimelb.edu.au

\section{References}

Ames, D. (2009). International Psychogeriatrics comes of age. International Psychogeriatrics, 21, 1-4.

Ames, D., Chiu, E., Lindesay, J. and Shulman, K. (2010). Guide to the Psychiatry of Old Age. Cambridge: Cambridge University Press.

Lautenschlager, N.T. et al. (2008). Effect of physical activity on cognitive function in older adults at risk for Alzheimer's disease: a randomized trial. $\mathcal{F A M A}, 300,1029-1037$. 